\title{
Interaction of Endothelin-1 with Vasoactive Factors in Mediating Glucose-Induced Increased Permeability in Endothelial Cells
}

\author{
Shali Chen, Margarita D. Apostolova, M. George Cherian, and Subrata Chakrabarti \\ Department of Pathology, University of Western Ontario, London, Ontario, Canada
}

SUMMARY: Alteration of endothelins (ET) and/or their receptors may be important in mediating vascular dysfunction in diabetes. We investigated mechanisms regulating ET-1 expression in human umbilical vein endothelial cells (HUVEC) in response to glucose and the functional significance of these mechanisms. Permeability across HUVEC, grown in medium containing either low $(5 \mathrm{mmol} / \mathrm{l})$ or high $(25 \mathrm{mmol} / \mathrm{l}) \mathrm{D}$-glucose were investigated. L-glucose was used as a control. ET-1, $\mathrm{ET}_{\mathrm{A}}$, and $\mathrm{ET}_{\mathrm{B}} \mathrm{mRNA}_{\mathrm{N}}$ were assessed by semiquantitative RT-PCR. ET-1 immunoreactivity and F-actin microfilament assembly were investigated using confocal microscopy. Increased transendothelial permeability was noted in cells cultured in high glucose or when the cells grown in low (physiologic) glucose were incubated with ET-1, vascular endothelial growth factor (VEGF), or N (G) -nitro-L-arginine methyl ester but not when they were incubated with $\mathrm{ET}-3, \mathrm{~N}(\mathrm{G})$-nitro-D-arginine methyl ester, or L-glucose. Increased permeability was associated with increased $E T-1, E_{A}$, and $E_{B}$ mRNA expression and augmented $E T-1$ immunoreactivity. High glucose induced increased permeability, increased $E T-1, E_{A}$, and $\mathrm{ET}_{\mathrm{B}} \mathrm{mRNA}$ expression. $\mathrm{ET}-1$ immunoreactivity was blocked by the protein kinase C (PKC) inhibitor chelerythrine, the specific PKC isoform inhibitor 379196, VEGF-neutralizing antibody, or the $E_{A}$ blocker TBC11251, but was not blocked by the specific $\mathrm{ET}_{\mathrm{B}}$ blocker BQ788 or by a VEGF-non-neutralizing antibody. Increased permeability was also associated with deranged F-actin assembly in the endothelial cells and by derangement of endothelial cell junctions as assessed by electron microscopy. Data from this study suggest that high glucose-induced increased permeability may be induced through increased ET-1 expression and disorganization of F-actin assembly. ET-1 expression and increased permeability may occur secondary to PKC isoform activation and may be modulated by VEGF and nitric oxide. (Lab Invest 2000, 80:1311-1321).

\begin{abstract}
$A$ bnormalities in vascular endothelial cells may be a key factor in the initiation of diabetes-induced functional and structural alterations in the target organs of diabetic complications (King et al, 1993; Porta, 1996). Several biochemical changes secondary to hyperglycaemia may occur in the target organs of diabetic complications. These may include polyol myo-inositol-related metabolic defect, non-enzymatic glycation, altered redox potential, and protein kinase C (PKC) activation (Brownlee et al, 1988; Greene et al, 1987; King et al, 1993; Koya and King, 1998; Williamson et al, 1993). These mechanisms are interactive and several, such as PKC activation and nonenzymatic glycation, may modulate gene expression of vasoactive factors. Alteration of vasoactive factors and their interactions may ultimately dictate vascular functional changes in diabetes (Porta, 1996). Several vasoactive factors may be important in diabetes. Among such factors, endothelins (ET) are produced by endothelial cells and several other cell types in the target organs of diabetic complications (Chakrabarti and Sima, 1997; Chakravarthy et al, 1994; MacCum-
\end{abstract}

Received May 1, 2000.

These studies were supported by a grant to SC from the Canadian Diabetes Association in honor of Florence Langillie.

Address reprint requests to: Dr. S. Chakrabarti, Department of Pathology, University of Western Ontario, London, Ontario, N6A 5A5. Fax: (519) 663-2930; E-mail:schakrab@julian.uwo.ca ber et al, 1991). ET are 21-amino acid vasoactive peptides with widespread tissue distribution and biological actions. ET act via three sets of receptors $\mathrm{ET}_{\mathrm{A}}$, $\mathrm{ET}_{\mathrm{B}}$, and $\mathrm{ET}_{\mathrm{C}}$ and transduce signals via a G-proteinmediated pathway (Simonson, 1993; Vanhoutte, 1994). We and others have previously shown that ET-1 and ET-3 mRNA, immunoreactive proteins, and their receptors are up-regulated in the retina of diabetic and galactose-fed rats (Chakrabarti et al, 1998; Chakravarthy et al, 1997; Deng et al, 1999; Evans et al, 1998). We have also demonstrated that treatment with a general ET receptor blocker can prevent short-term diabetes and galactosemia-induced increase in resistivity index (a marker for vasoconstriction) in the rat retinal vasculature (Deng et al, 1999; Evans et al, 1998). Similar vascular dysfunction in the retina has also been prevented by treatment with a PKC inhibitor (Ishii et al, 1996). ET-1 antagonism prevented diabetes-induced vasoconstriction and reduced nerve conduction velocity in the peripheral nerve (Cameron et al, 1994). ET-1 has several biologic activities (Levin, 1995). In addition to being the most potent vasoconstrictor, ET-1 acts as a permeability factor in the vascular endothelium (Levin, 1995; Simonson, 1993; Vanhoutte, 1994). In long-term diabetes, ET may regulate extracellular matrix protein gene expression in the target organs of diabetic complications (Evans et al, 1999; Nakamura et al, 1995). In kidneys from streptozotocin-induced diabetic rats, increased extra- 
cellular matrix protein production is ameliorated by treatment with an $\mathrm{ET}_{\mathrm{A}}$ inhibitor (Nakamura et al, 1995). ET-1 expression is modulated by PKC and vice versa (Levin, 1995; Simonson, 1993; Vanhoutte, 1994). Moreover, vascular endothelial growth factor (VEGF), which probably acts as a permeability factor in diabetes, is further activated in hyperglycaemia via a PKCdependent pathway (Aiello et al, 1997). The possibility of a co-stimulatory relationship between VEGF and ET-1 has also been suggested (Pedram et al, 1997). Among the vasodilators, a feedback regulatory mechanism exists between ET-1 and the well known vasodilator, nitric oxide (NO), in which increased NO inhibits ET-1 synthesis and increased ET-1 inhibits NO synthesis (Levin, 1995; Simonson, 1993; Vanhoutte, 1994).

Conceptually, ET-1 may interact with several other vasoactive factors in mediating its effect in diabetes. To further explore the mechanisms of ET-1 action in hyperglycaemia and to delineate its relationship with PKC, NO, and VEGF, we investigated ET-1 and its receptor expression, their functional significance and their interaction with other vasoactive factors in HUVEC.

\section{Results}

\section{Cell Viability and Proliferation}

Cell viability (assessed by trypan blue dye exclusion) did not show any significant differences between cells cultured in $5 \mathrm{mmol} / \mathrm{l}$ of glucose (physiologic) and in 25 $\mathrm{mmol} / \mathrm{l}$ of glucose (high) for up to 96 hours. Cell proliferation (assessed by XTT assay) showed a sig- nificantly $(p<0.008)$ lower cell proliferation rate after 72 hours in cells cultured under hyperglycaemic conditions (1.128 \pm 0.002$)$ compared with cells cultured under normoglycaemic conditions (1.964 \pm 0.028$)$.

\section{Cell Permeability}

When HUVEC in $5 \mathrm{mmol} / \mathrm{l}$ of glucose were exposed to ET-1, VEGF, or N(G)-nitro-L-arginine methyl ester (L-NAME), but not to $N(G)$-nitro-D-arginine methyl ester (D-NAME), an increase in permeability across the endothelial cell barrier was observed. The PKC activator PMA also caused increased permeability. Incubation of HUVEC with D-glucose caused an increase in the permeability across the endothelial cell barrier (Fig. 1). Incubation with $25 \mathrm{mmol} / \mathrm{l}$ of L-glucose for up to 96 hours did not produce any change in the permeability. Increased permeability induced by a high glucose level was completely blocked by a specific $\mathrm{ET}_{\mathrm{A}}$ blocker, TBC11251. When the cells were incubated with the general PKC inhibitor chelerythrine, the specific PKC inhibitor 379196, or the specific $E T_{B}$ blocker BQ788, the permeability was significantly reduced, but did not reach the level of reduction seen with TBC11251. When the cells were treated with a VEGF-neutralizing antibody, a similar effect was seen. Treatment with genistein or a VEGF-non-neutralizing antibody did not have any effect on glucose-induced increased permeability (Fig. 1).

\section{mRNA Expression}

Incubation of HUVEC with glucose caused a dose- and time-dependent increase in ET-1 mRNA expression as-
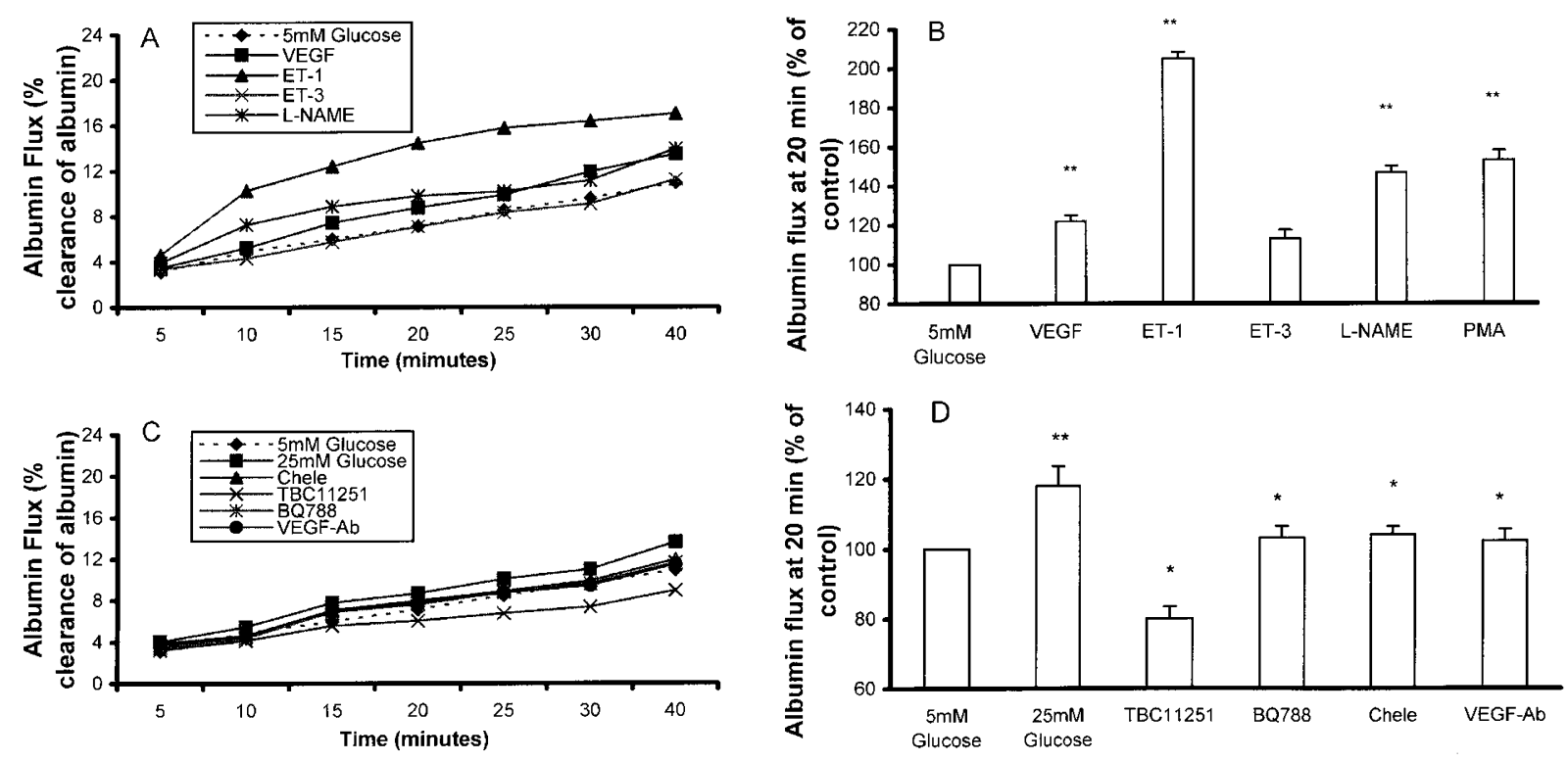

Figure 1.

Permeability alteration in HUVEC incubated in $5 \mathrm{mmol} / \mathrm{l}$ of D-glucose (A and B) and in $25 \mathrm{mmol} / / \mathrm{l}$ of $\mathrm{D}$-glucose (C and D). (Chele, chelerythrine; VEGF-Ab, vascular endothelial growth factor-neutralizing antibody). Increased permeability was seen when the cells were incubated in $25 \mathrm{mmol} / \mathrm{l}$ of D-glucose, which was prevented by TBC11251, the PKC inhibitor chelerythrine, VEGF-neutralizing antibody, and the $\mathrm{ET}_{\mathrm{B}}$ blocker BQ788. Increased permeability was also seen when HUVEC in 5 mmol/l of D-glucose were exposed to ET-1, VEGF, PMA, or N (G) -nitro-L-arginine methyl ester (L-NAME), but not to N(G)-nitro-D-arginine methyl ester (D-NAME). Values are expressed as mean \pm SEM of three different experiments. B and D show comparisons of various groups at 20 minutes. **, significantly different from $5 \mathrm{mmol} / \mathrm{l}$ of glucose; ${ }^{*}$, significantly different from $25 \mathrm{mmol} / \mathrm{l}$ of glucose. 
sessed by semiquantitative RT-PCR; peaking at 30 $\mathrm{mmol} / \mathrm{l}$ of glucose or after 72 hours at $25 \mathrm{mmol} / \mathrm{l}$ (Fig. 2). Similar increases were seen in $\mathrm{ET}_{\mathrm{A}}$ and $\mathrm{ET}_{\mathrm{B}} \mathrm{mRNA}$ levels. The changes in ET-1 mRNA expression correlated with the permeability results. The increase in ET-1 mRNA expression induced by high glucose was completely prevented by incubation with the general PKC inhibitor chelerythrine, the specific PKC inhibitor 379196, or the VEGF-neutralizing antibody. Because chelerythrine, 379196, and VEGF-neutralizing antibody reduced ET-1 expression below the basal level, we investigated the effects of these compounds on basal ET-1 mRNA expression. Each of these compounds significantly inhibited basal ET-1 mRNA synthesis in physiologic (5 $\mathrm{mmol} / \mathrm{l})$ glucose (data not shown). No effects were observed when cells in high glucose were incubated with the VEGF-non-neutralizing antibody, BQ788, or with the PKA inhibitor N-tosyl-N-phenylalanin chlormethyl (data not shown). Interestingly, TBC11251 had some inhibitory effects on ET-1 mRNA expression. Cells in $5 \mathrm{mmol} / \mathrm{l}$ of glucose incubated with VEGF or L-NAME showed similar increases in $E T-1, E T_{A}$, and $E T_{B} m R N A$. Incubation with $25 \mathrm{mmol} / \mathrm{l}$ of L-glucose did not produce any changes in the expression of these mRNA (Fig. 2). Incubation with $25 \mathrm{mmol} / \mathrm{l}$ of D-glucose but not L-glucose also caused increased VEGF mRNA (all isoforms) expression (data not shown).

\section{Immunoreactive ET-1 Protein Expression by Confocal Microscopy}

Data from ET-1 immunofluorescence and confocal microscopy of the HUVEC were similar to the mRNA
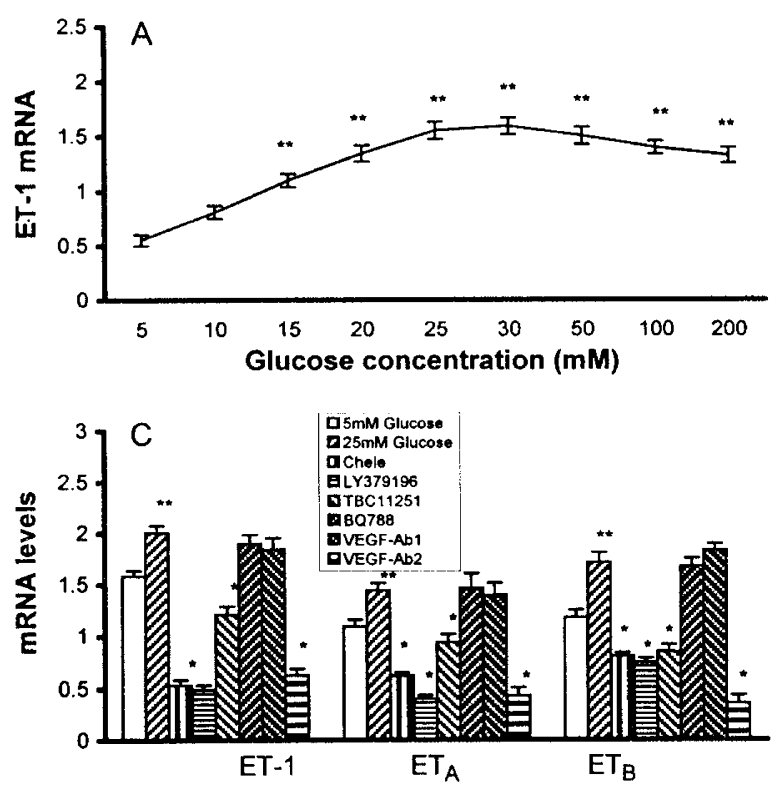

expression data. Incubation of HUVEC with $25 \mathrm{mmol} / \mathrm{l}$ of glucose caused increased ET-1 immunoreactivity. Similar increased ET-1 immunoreactivity was also seen when cells grown in $5 \mathrm{mmol} / \mathrm{l}$ of glucose were incubated with L-NAME (not with D-NAME) or VEGF (Fig. 3). The increased immunoreactivity induced by high glucose was prevented by the general PKC inhibitor chelerythrine, the specific PKC inhibitor 379196, or the VEGFneutralizing antibody. TBC11251 incubation produced slightly reduced immunoreactivity. No effects were seen when the cells in high glucose were incubated with VEGF-non-neutralizing antibody or BQ788.

\section{F-Actin Staining}

At normal glucose levels, most of the actin filaments were arranged along the periphery of the cells; very few fibers were seen at the center. Incubation of HUVEC in $5 \mathrm{mmol} / \mathrm{l}$ of glucose with ET-1 (but not ET-3), L-NAME, or VEGF, or in $25 \mathrm{mmol} / \mathrm{l}$ of D-glucose (but not L-glucose) produced diffuse and irregular actin filament patterns with increasing accumulations of filaments in the cell centers, stress fiber formation, a particulate immunoreactivity pattern, and higher overall immunoreactivity. Incubation of cells cultured in $25 \mathrm{mmol} / \mathrm{l}$ of glucose with TBC11251 or BQ788 showed partial protection against glucose-induced actin fiber disorganization. Although there were some filaments in the center, most were present at the periphery. Incubation with chelerythrine, 379196, and VEGF-neutralizing antibody had similar effects (Fig. 4).
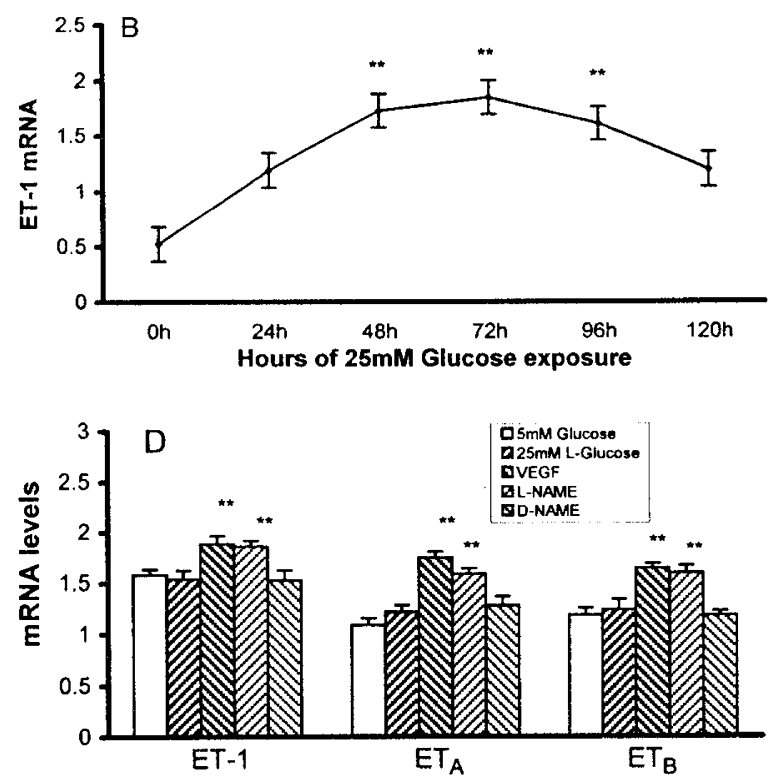

\section{Figure 2.}

Incubation of HUVEC in D-glucose caused dose-dependent (A) and time-dependent (B) increases in ET-1 mRNA expression by semiquantitative RT-PCR. C, High glucose $(25 \mathrm{mmol} / \mathrm{l})$-induced increased mRNA expression for ET-1 was completely prevented by the general PKC inhibitor chelerythrine (Chele), the specific PKC inhibitor 379196 (LY379196), or VEGF-neutralizing antibody (VEGF-Ab2). No effects were seen when the cells in 25 mmol/l of D-glucose were incubated with VEGF-non-neutralizing antibody (VEGF-Ab1) or BQ788. D, When cells in $5 \mathrm{mmol} / \mathrm{l}$ of D-glucose were incubated with VEGF or L-NAME, increased ET1 mRNA was observed. Similar changes in $\mathrm{ET}_{\mathrm{A}}$ and $\mathrm{ET}_{\mathrm{B}} \mathrm{mRNA}$ were also seen $(\mathrm{C}$ and $\mathrm{D})$. Incubation with $25 \mathrm{mmol} / \mathrm{l}$ of $\mathrm{L}$-glucose did not show any change in the expression of these mRNA (D). All mRNA levels are expressed as ratios to the $\beta$-actin mRNA level. ${ }^{\star *}$, significantly different from $5 \mathrm{mmol} / \mathrm{l}$ of glucose (A, C, D) or from 0.5 hours of exposure (B). ${ }^{*}$, significantly different from $25 \mathrm{mmol} / \mathrm{l}$ of glucose. Values are expressed as mean \pm SEM of three different experiments. 

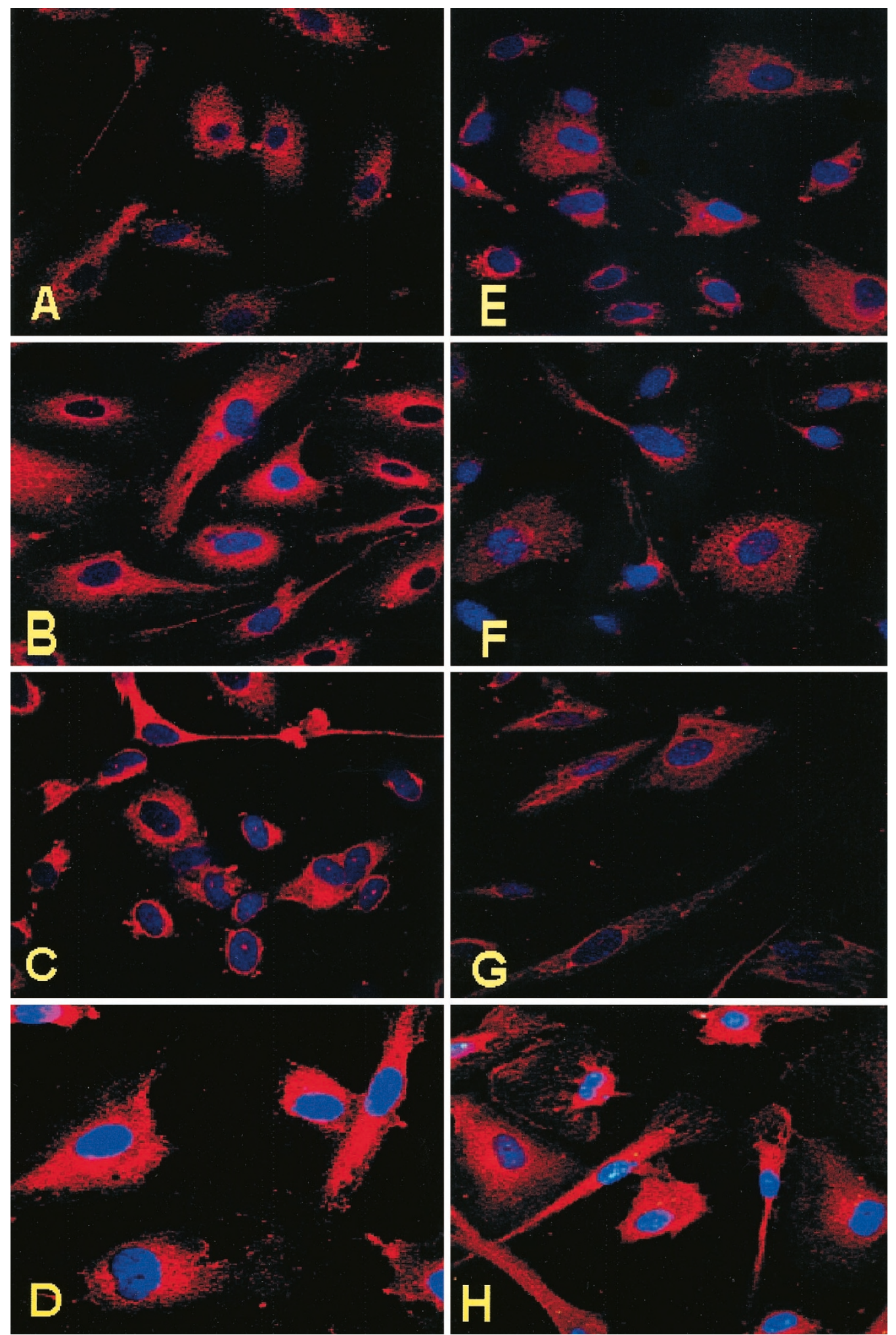

\section{Figure 3.}

Immunoreactive ET-1 protein expression by confocal microscopy of HUVEC incubated with (A) $5 \mathrm{mmol} / \mathrm{l}$ of D-glucose, (B) $5 \mathrm{mmol} / \mathrm{l}$ of D-glucose with VEGF, (C) 5 $\mathrm{mmol} / / \mathrm{l}$ of D-glucose with L-NAME, (D) $25 \mathrm{mmol} / \mathrm{l}$ of D-glucose, (E) $25 \mathrm{mmol} / \mathrm{l}$ of D-glucose with chelerythrine, (F) $25 \mathrm{mmol} / \mathrm{l}$ of D-glucose with 379196 , (G) $25 \mathrm{mmol} / \mathrm{l}$ of D-glucose with VEGF-neutralizing antibody, or (H) $25 \mathrm{mmol} / \mathrm{l}$ of D-glucose with VEGF-non-neutralizing antibody. High (25 mmol/l) D-glucose (D) as well as VEGF

(B) and L-NAME (C) produced increased ET-1 immunoreactivity. The glucose-induced increase in immunoreactivity was prevented by chelerythrine (E), $379196(\mathrm{~F})$, or VEGF-neutralizing antibody (G), but not by VEGF-non-neutralizing antibody (H). (Original magnification, $\times 1000$ ) 

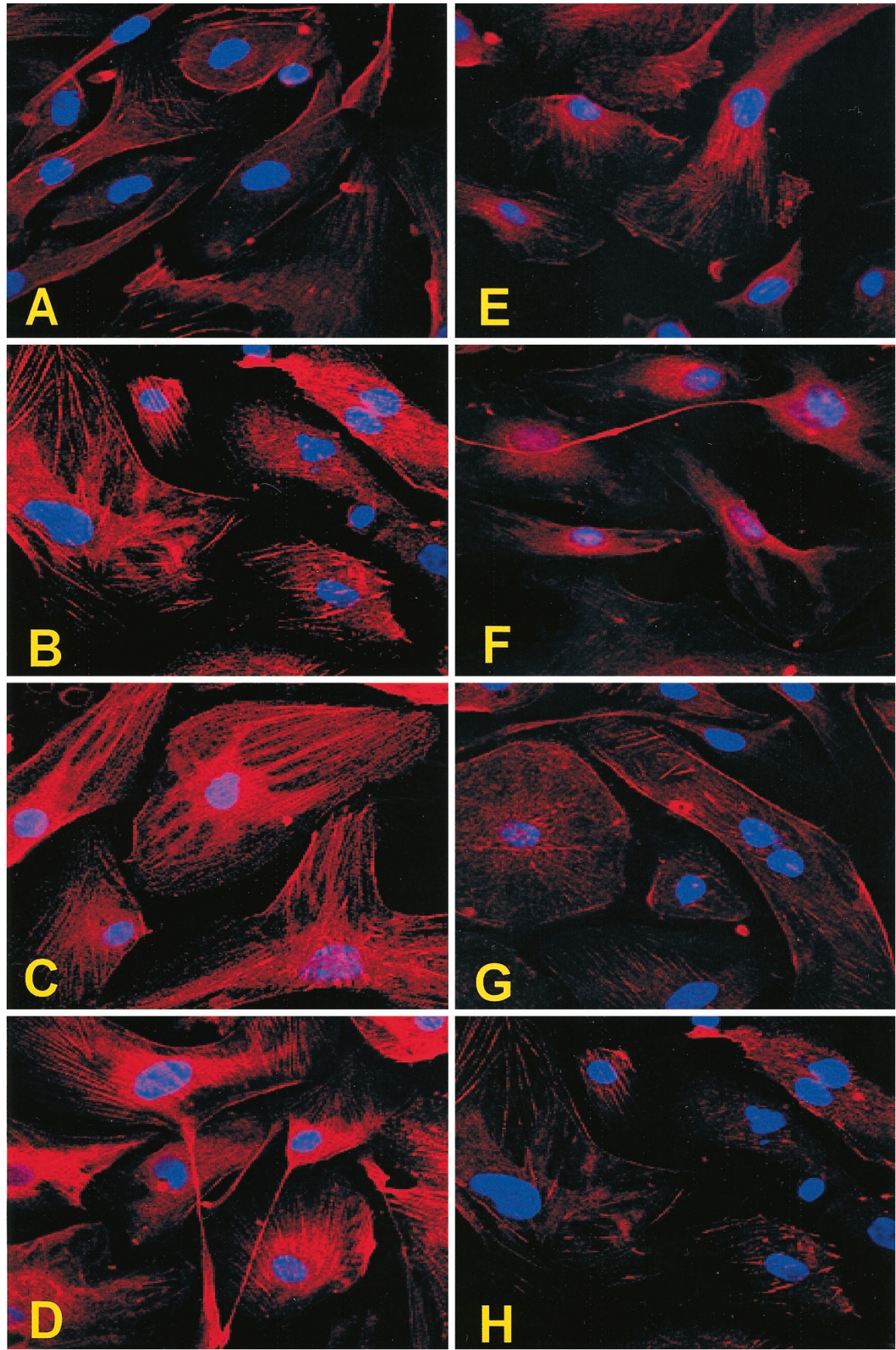

\section{Figure 4.}

F-actin staining (alexa-labeled phalloidin) by confocal microscopy of HUVEC incubated with (A) $5 \mathrm{mmol} / \mathrm{l}$ of D-glucose, (B) $5 \mathrm{mmol} / \mathrm{l}$ of D-glucose with VEGF, (C) 5 $\mathrm{mmol} / \mathrm{l}$ of D-glucose with L-NAME, (D) $25 \mathrm{mmol} / / \mathrm{l}$ of D-glucose, (E) $25 \mathrm{mmol} / / \mathrm{l}$ of D-glucose with TBC11251, (F) $25 \mathrm{mmol} / /$ of D-glucose with chelerythrine, (G) 25 $\mathrm{mmol} / \mathrm{l}$ of D-glucose with 379196, (H) $25 \mathrm{mmol} / \mathrm{l}$ of D-glucose with VEGF-neutralizing antibody. High (25 mmol/l) D-glucose (D) as well as VEGF (B) and L-NAME (C) caused alteration of actin microfilament assembly, which was prevented by TBC11251 (E), chelerythrine (F), $379196(G)$, or VEGF-neutralizing antibody (H). (Original magnification, $\times 1000)$ 


\section{Electron Microscopy}

Electron microscopic analysis of the endothelial cells showed intact cell junctions among endothelial cells incubated in $5 \mathrm{mmol} / \mathrm{l}$ of D-glucose. However, incubation of cells in $25 \mathrm{mmol} / \mathrm{l}$ of D-glucose or in ET-1 (which lead to increased permeability) produced disruptions of the endothelial cell junctions (Fig. 5).

\section{Discussion}

We demonstrated that augmented ET-1 production in hyperglycaemia causes increased permeability across endothelial cell barriers. Additionally, our data demonstrate interesting interactions among various vasoactive factors in the production of increased permeability. ET-1 was previously known to increase endothelial cell permeability. In the present study, cells grown in 5 $\mathrm{mmol} / \mathrm{l}$ of glucose showed increased transendothelial permeability when incubated with ET-1 but not when incubated with ET-3. Both VEGF and L-NAME caused increases in permeability in association with increased ET-1 mRNA and immunoreactive protein expression. Similar increases in permeability were seen with the PKC stimulator PMA. A stimulatory interaction of ET-1
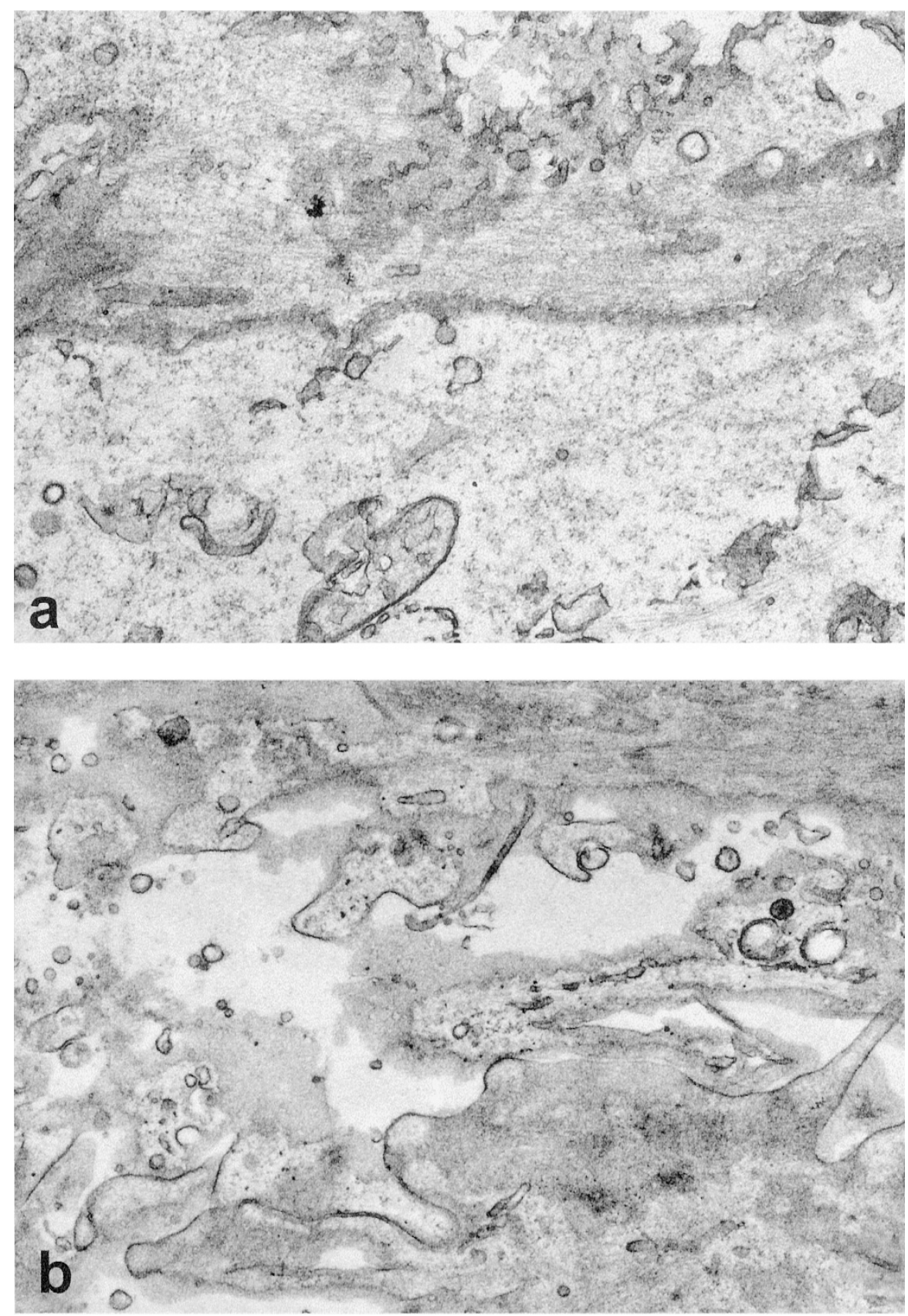

Figure 5.

Electron micrographs of HUVEC incubated with (a) $5 \mathrm{mmol} / \mathrm{l}$ of D-glucose or (b) $25 \mathrm{mmol} / /$ of D-glucose. Note disruption of endothelial cell junctions in (b) compared with (a). Similar changes were observed when cells in $5 \mathrm{mmol} / \mathrm{l}$ of $\mathrm{D}$-glucose were incubated with ET-1. Original magnification, $\times 20,000$. 
and VEGF has previously been described (Matsuura et al, 1998; Pedram et al, 1997). In this study, cells incubated in high glucose showed increased VEGF mRNA expression similar to previous studies (Duh and Aiello, 1999). Thus, it is possible that both PKC activation and increased VEGF may contribute to increased ET-1 mRNA expression and increased permeability. Our study shows that, similar to the euglycemic condition, a stimulatory relationship between ET-1 and VEGF may be important in inducing increased transendothelial permeability mediated by glucose in hyperglycaemia. Additionally, a reciprocal relation exists between ET-1 and NO (Levin, 1995; Simonson, 1993; Vanhoutte, 1994). Among the inhibitors used to block hyperglycaemia-induced permeability, blockage of $\mathrm{ET}_{\mathrm{A}}$ was the most effective; although significant reduction was also seen with VEGFneutralizing antibody, and general and specific PKC isoform inhibition as well as $\mathrm{ET}_{\mathrm{B}}$ receptor blockade. VEGF-neutralizing antibody reduced the ET-1 mRNA and protein expression induced by high glucose as well as $\mathrm{ET}_{\mathrm{A}}$ and $\mathrm{ET}_{\mathrm{B}} \mathrm{mRNA}$ expression, and increased endothelial cell permeability. Furthermore, VEGF in HUVEC grown in normal glucose increased ET-1, ET ${ }_{A}$, and $\mathrm{ET}_{\mathrm{B}} \mathrm{mRNA}$ expression along with endothelial cell permeability. Thus, at least part of the VEGF-induced increased permeability in early diabetes is probably mediated via ET-1. The efficacy of VEGF-neutralizing antibody used in this study has previously been examined in animal experiments (Kanai et al, 1998 ). A non-neutralizing antibody provided adequate control for these experiments. The present study suggests that the ET-1-mediated permeability alteration in HUVEC in hyperglycaemia is mediated via both ET receptors. Because blockade of the $\mathrm{ET}_{\mathrm{A}}$ receptor was more effective than blockade of $\mathrm{ET}_{B}$ receptors, the $\mathrm{ET}_{\mathrm{A}}$ receptor may be the main receptor by which $\mathrm{ET}-1$ modulates glucose-induced increased permeability. However, this study also demonstrated that basal ET-1 mRNA expression and augmented ET-1 mRNA expression in hyperglycaemia are mediated in part via the PKC isoform. This isoform has been identified as important in mediating vasoconstriction in early diabetes (Ishii et al, 1996; Koya and King, 1998).

The increased permeability and augmented ET-1 expression was associated with defective F-actin microfilament assembly in hyperglycaemia. These changes were partially corrected by ET receptor antagonists, general PKC and PKC, and VEGF neutralization.

Reorganization of actin microfilament assembly has previously been demonstrated in endothelial cells grown in high glucose-containing media and in retinal capillary endothelial cells in diabetes (Salameh et al, 1997; Yu et al, 1998). Furthermore, in certain conditions, increased endothelial permeability and increased ET-1 expression in endothelial cells has been associated with deranged actin assembly (Kolodgie et al, 1999; Malek et al, 1997). Our data suggest that actin filament reorganization may represent a mechanism by which ET-1-mediated increased permeability across the endothelial cells is mediated in response to hyperglycaemia. Additionally, we have demonstrated disruption of endothelial cell junctions in association with increased permeability. These two mechanisms are probably related (Zhou et al, 1995). However, other mechanisms may also be involved. Interestingly, ETconverting enzyme has recently been localized to the F-actin microfilament in smooth muscle cells (Barnes and Turner, 1999).

Increased vascular permeability is an important pathogenetic feature of endothelial cell dysfunction in diabetic microangiopathy. Alteration of the ET system has been demonstrated in several target organs of diabetic complications in association with functional alteration of blood flow in these organs (Cameron et al, 1994; Chakrabarti et al, 1998; Chakravarthy et al, 1997; Deng et al, 1999; Evans et al, 1998). Increased serum levels of ET-1 has been demonstrated in diabetic patients and in animal diabetes (Hopfner et al, 1999; Tarquini et al, 1997). Our study suggests that a similar ET-related mechanism may be involved in mediating hyperglycaemia-induced permeability alteration in diabetes. The importance of ET alteration is increasingly being recognized as an important mechanism in the generation of several disorders involving vasculature, including diabetic complications (Caballero et al, 1999; Levin, 1995; Sarman et al, 1998; Simonson, 1993; Vanhoutte, 1994). The effects of ET overexpression may vary during early and late diabetes (Chakrabarti et al, 1998; Deng et al, 1999; Evans et al, 1999; Hopfner et al, 1999). In early diabetes, ET-mediated vasoconstriction and/or permeability alterations are important; whereas in chronic diabetes, up-regulation of ET may lead to increased extracellular matrix protein synthesis and structural alterations, as shown in the kidney and retina of diabetic animals (Chakrabarti et al, 1998; Deng et al, 1999; Evans et al, 1999). However, other factors derived from the endothelium and from various adjacent cells may interact and modulate ET effects. The ultimate results of these interactions would subsequently manifest as functional and/or structural alterations in the target organs of diabetic complications. Data from this and other studies also suggest that ET-receptor blockade may represent a potential adjuvant therapeutic pathway for the treatment of diabetic complications.

\section{Materials and Methods}

\section{Reagents}

All reagents were obtained from Sigma Chemical Company, St. Louis, Missouri unless otherwise mentioned.

\section{Cell Culture}

The HUVEC line was obtained from American Type Culture Collection (Rockville, Maryland). These cells were plated at 2500 cells $/ \mathrm{cm}^{2}$ in Endothelial Cell Growth Medium (EGM) (Clonetics, Walkersvile, Maryland). EGM is a modified MCDB 131 formulation and is supplied with $10 \mathrm{ng} / \mathrm{ml}$ of human recombinant epidermal growth factor, $1.0 \mu \mathrm{g} / \mathrm{ml}$ of hydrocortisone, 50 
$\mu \mathrm{g} / \mathrm{ml}$ of Gentamicin, $50 \mathrm{ng} / \mathrm{ml}$ of Amphotericin B, 12 $\mu \mathrm{g} / \mathrm{ml}$ of bovine brain extract, and $10 \%$ fetal bovine serum. Cells were grown in $25 \mathrm{~cm}^{2}$ tissue culture flasks. Appropriate concentrations of glucose were added to the media when cells were $80 \%$ confluent. For permeability assays, HUVEC were grown in inserts (see "Permeability Assay") and incubated at $37^{\circ} \mathrm{C}$ in $5 \% \mathrm{CO}_{2}$ until confluent.

\section{Cell Proliferation and Cell Viability}

Cell viability was measured by trypan blue dye exclusion and cell proliferation was evaluated by the microculture tetrazolium assay using XTT (2, 3-bis (2methoxy-4-nitro-5-sulfophenyl)-5-[(phenylamino)

carbonyl]-2H-tetrazolium hydroxide) (Scudiero et al, 1988). Cells were seeded in 96-well plates $(3,200$ cells/well, 10,000 cells $/ \mathrm{cm}^{2}$ ) in $100 \mu$ l. After 24 hours, experimental agents were applied (100 $\mu \mathrm{l})$ and the cultures were incubated for 1,3 , or 5 days at $37^{\circ} \mathrm{C}$. Fifty micrograms of XTT and $0.38 \mu \mathrm{g}$ of phenazine methosulfate were added to each well (50 $\mu$ l) after cell inoculation. The cells were incubated at $37^{\circ} \mathrm{C}$ for 4 hours, the plates were mixed on a mechanical plate shaker, and absorbance at $450 \mathrm{~nm}$ was measured with the Bio-Rad Model 3550 Microplate Reader (BioRad Laboratories, Hercules, California). Experiments were performed in triplicate.

\section{Permeability Assay}

For the detection of permeability, albumin diffusion across endothelial monolayers was studied (Bonner and O'Sullivan, 1998). Cell culture inserts (3.0 $\mu \mathrm{m}$; Becton Dickinson Labware, Franklin Lake, New Jersey) were coated with $50 \mu \mathrm{g} / \mathrm{ml}$ of type I collagen in 20 $\mathrm{mmol} / \mathrm{l}$ of acetic acid for 1 hour at $23^{\circ} \mathrm{C}$. Inserts were then washed with HEPES buffered saline $(137 \mathrm{mmol} / \mathrm{l}$ of $\mathrm{NaCl}, 4 \mathrm{mmol} / \mathrm{l}$ of $\mathrm{KCl}, 6 \mathrm{mmol} / \mathrm{l}$ of glucose, and 20 $\mathrm{mmol} / \mathrm{l}$ of HEPES, $\mathrm{pH} 7.45)$ to remove excess protein. Complete medium was added to both insert and well, and the membrane was equilibrated for 3 hours at $37^{\circ} \mathrm{C}$ in $5 \% \mathrm{CO}_{2}$. HUVEC were trypsinized from tissue culture flasks, washed three times with complete medium, and grown on inserts at $8 \times 10^{5}$ cells/insert. The inserts were incubated at $37^{\circ} \mathrm{C}$ in $5 \% \mathrm{CO}_{2}$, and the cultures were examined by phase-contrast microscopy after 2 to 4 days. Stimuli and inhibitors were added to both the insert and the lower well. HUVEC monolayers grown on inserts were gently washed with HBSS and incubated in 6-well plates containing $3 \mathrm{ml}$ of HBSS per well. The monolayers were covered immediately with $2 \mathrm{ml}$ of HBSS containing a trypan blue-albumin complex (trypan blue 0.035\%, BSA $0.8 \%$ ). Fluid volumes were selected to yield no hydrostatic gradient across the monolayer. The preparations were incubated at $37^{\circ} \mathrm{C}$ and $5 \% \quad \mathrm{CO}_{2}$ with continuous agitation. Samples were collected every 5 minutes from the bottom well up to 40 minutes and were replaced by an equal volume of HBSS. Absorbance at $590 \mathrm{~nm}$ was measured from both the insert and the lower well fluids. Results were expressed as percentage clearance of BSA as previously described (Bonner and O'Sullivan, 1998). Cells were incubated with $5 \mathrm{mmol} / \mathrm{l}$ or $25 \mathrm{mmol} / \mathrm{l}$ of glucose for 96 hours and for an additional 30 minutes with the stimulator or inhibitor before the assessment of permeability. Twenty-five millimoles/liter of L-glucose was used as control. In all experiments, L-NAME, D-NAME, the specific $\mathrm{ET}_{\mathrm{A}}$ blocker TBC11251 (courtesy of Dr. R. Tilton, Texas Biotechnology Corporation, Houston, Texas), and the PKA inhibitor N-tosyl-N-phenylalanin chlormethyl were used at $10 \mu \mathrm{mol} / \mathrm{l}$. PMA was used at $60 \mathrm{ng} / \mathrm{l}$. The selective $\mathrm{ET}_{\mathrm{B}}$ blocker $\mathrm{BQ788}$ and the PKC inhibitor chelerythrine were used at $1 \mu \mathrm{mol} / \mathrm{l}$. VEGF was used at $50 \mathrm{ng} / \mathrm{ml}$; VEGF antibodies (R and D Systems, Minneapolis, Minnesota) at $0.1 \mu \mathrm{g} / \mathrm{ml} ; 379196$ (courtesy Dr. D. Kirkways, Eli Lilly Company, Indianapolis, Indiana) at 30 nmol/l; and ET-1 and ET-3 (Peninsula Laboratories, Belmont, California) at $500 \mathrm{pmol} / \mathrm{l}$.

\section{Confocal Microscopy}

Cells grown on $18 \mathrm{~mm}$ round coverslips in 12-well plates were washed with EGM and incubated with experimental agents diluted in EGM. The concentration and exposure time of the agents were determined in preliminary experiments. Fluorescence cell labeling was performed after fixation with methanol:acetone $(1: 1, v / v)$ and permeabilization in $0.1 \%$ Triton $X-100$ for 30 minutes. Non-specific immunoreactivity was blocked with $5 \%$ normal goat serum and $1 \%$ BSA in PBS containing $0.1 \%$ Tween-20 for 1 hour at room temperature. Purified polyclonal ET-1 rabbit antibody (Peninsula Laboratories) in blocking solution was added to the slides for 1 hour at room temperature. The cells were washed three times with PBS for 5 minutes and incubated for 40 minutes with goat antirabbit IgG labeled with Texas Red (Vector Laboratories, Burlington, Ontario, Canada). After three washes in PBS and two washes in water, slides were mounted in Vectashield fluorescence mounting medium with DAPI (Vector Laboratories) for nuclear staining.

Fluorescence microscopy was performed by an examiner unaware of the identity of the sample using a Zeiss LSM 410 inverted laser scan microscope equipped with fluorescein, rhodamine, and DAPI filters (Carl Zeiss Canada Ltd., North York, Ontario, Canada).

\section{F-Actin Staining}

F-actin staining was performed according to a previously described methodology (Zheng et al, 1996). Briefly, confluent monolayers of cells in various conditions were rinsed with PBS, fixed in methanol:acetone $(1: 1, v / v)$ for 10 minutes on ice, washed with PBS, incubated with alexa-labeled phalloidin (Molecular Probes Inc., Eugene, Oregon) for 40 minutes at room temperature, washed extensively with PBS, and mounted with Vectashield fluorescence mounting media (Vector Laboratories) and examined on a Zeiss LSM 410 inverted laser scan microscope (Carl Zeiss Canada Ltd.) by an examiner unaware of the specimen identity. 


\section{Electron Microscopy}

After permeability experiments, the inserts with attached HUVEC were fixed in $2.5 \%$ glutaraldehyde in phosphate buffer and processed for EPON embedding. Ultrathin sections on 200 mesh nickel grids were stained with uranyl acetate and lead citrate and examined electronmicroscopically.

\section{RNA Isolation}

TRIZOL reagent (Canadian Life Technologies Inc., Burlington, Ontario, Canada) was used to isolate RNA. RNA was extracted with chloroform followed by centrifugation to separate the solution into aqueous and organic phases. RNA was recovered from the aqueous phase by precipitation with isopropyl alcohol and suspended in DEPC-treated water. Quantitation of RNA was performed by determining the absorbances at $260 \mathrm{~nm}$ and $280 \mathrm{~nm}$.

\section{First Strand cDNA Synthesis}

First strand cDNA synthesis was performed using Superscript-II system (Canadian Life Technologies Inc.). RNA was added to Oligo (dT) primers (Canadian Life Technologies Inc.), denatured at $65^{\circ} \mathrm{C}$, and quenched on ice for 10 minutes. Reverse transcription was carried out by the addition of MMLV-reverse transcriptase and dNTP at $42^{\circ} \mathrm{C}$ for 50 minutes in a total reaction volume of $20 \mu \mathrm{l}$. The reaction was terminated by a 15 -minute incubation at $70^{\circ} \mathrm{C}$. The resulting $\mathrm{RT}$ products were stored at $-20^{\circ} \mathrm{C}$.

\section{Polymerase Chain Reaction}

The amplification was carried out as previously described (Chakrabarti et al, 1998; Deng et al, 1999) using the following cDNA sequences. For ET-1, primer 1 (antisense, 5'-GGACATCATTTGGGTCAACACTCC$3^{\prime}$ ) and primer 2 (sense, 5'-CCAATCTTGGAACAGTCTTTTCCT-3') with a predicted product size of 269 bp were used; for $\mathrm{ET}_{\mathrm{A}}$, primer 1 (antisense, 5'-TGGCCTTTTGATCACAATGACTTT-3') and primer 2 (sense, 5' -TTTGATGTGGCATTGAGCATACAGGTT$\left.3^{\prime}\right)$ with a predicted product size of 302bp were used; for $\mathrm{ET}_{\mathrm{B}}$, primer 1 (antisense, 5'-ACTGGCCATTTGGAGGTGAGATGT-3') and primer 2 (sense, 5-CTGCATGCCACTTTTCTITCTCAA-3') with a predicted product size of 428 bp were used (Adner et al, 1996; Berge et al, 1997). For VEGF primers, primer 1 (antisense, 5'-GTCAGTGGCCTTGTGAGCATG-3') and primer 2 (sense, 5'-CAGATAGTCAGGGATCATGGGA-3') were used, with expected product sizes of 635bp, 563bp, and $431 \mathrm{bp}$ for VEGF 188, VEGF 164, and VEGF 120, respectively (Cullinan-Bove and Koos, 1993). Reactions were performed in $30 \mu \mathrm{l}$ volumes containing $1 \mathrm{x}$ PCR-buffer, $1.5 \mathrm{mmol} / \mathrm{l}$ of $\mathrm{MgCl}_{2}, 250 \mu \mathrm{M}$ of dNTP mix, $1 \mu \mathrm{M}$ of each amplification primer, $2.5 \mathrm{U}$ of Taq polymerase, and $4 \mu \mathrm{l}$ of the RT product. The amplification for $\mathrm{ET}-1, \mathrm{ET}_{\mathrm{A}}$, and $\mathrm{ET}_{\mathrm{B}}$ were carried out as follows: 1 minute at $94^{\circ} \mathrm{C}$ (denaturation), 1 minute at $54^{\circ} \mathrm{C}$ (annealing), and 3 minutes at $72^{\circ} \mathrm{C}$ (extension).
For $E T-1$ and $E T_{B}, 30$ cycles of amplification were performed; for $\mathrm{ET}_{\mathrm{A}}, 40$ cycles of amplification were performed. Simultaneously, a housekeeping gene $(\beta-$ actin) was amplified in a separate set of tubes using the same RT product and similar cycling parameters; 5'-CCTCTATTCCAACACAGTGC-3' and 5'-CATCGTACTCCTGCTTGCTG-3' primer sets with a predicted product size of $210 \mathrm{bp}$ were used.

The amplification products were analyzed on a $3 \%$ agarose gel in $1 \times$ tris-acetate-EDTA buffer. Eight microliters of each PCR product was subjected to electrophoresis at 110 volts for 60 minutes. The gels were stained with ethidium bromide and visualized under UV light. Positive amplification for ET-1, $\mathrm{ET}_{\mathrm{A}}$, $\mathrm{ET}_{\mathrm{B}}$, and $\beta$-actin were demonstrated as single bands of the desired size.

\section{Southern Hybridization}

The specificities of the amplifications were confirmed by southern blot after transferring the PCR product from the gel onto nylon membranes after denaturation and neutralization. Hybridizations were performed with biotinylated amplification product-specific oligoprobes (ET-1: 5'-TGCCAAGCATGAAAAGAACT-3', $\mathrm{ET}_{\mathrm{A}}$ : 5'-GGAATTGGGATTCCTTTGGT-3', and ET B $_{\mathrm{B}}$ : 5' TCCCGTTCAGAAGACAGCTT-3') (Adner et al, 1996; Berge et al, 1997). A similar amplification productspecific oligoprobe (5'-GCTCTATCCTGGCCTCACTG-3') was used for $\beta$-actin. Detection was carried out using a nitroblue tetrazolium/5-bromo-4-chloro-3indolyl phosphate (NBT/BCIP) (Life Technologies Inc., Burlington, Ontario, Canada) system.

\section{Quantitation}

Quantitation was performed by serial dilution and slot-blot hybridization and densitometry of the amplification products from the upstream primer (after 35 cycles for peptide mRNA and 30 cycles for receptor mRNA) on nylon membranes as previously described (Chakrabarti et al, 1998; Deng et al, 1999). Hybridization was performed using the biotinylated oligoprobes as described above and detection was performed by NBT/BCIP. The plates were analyzed by a HewlettPackard 4C scanner (Hewlett-Packard, Avondale, Pennsylvania) and using Mocha software (SPSS Inc., Chicago, Illinois). The densitometric values were expressed as arbitrary units per $\mu \mathrm{g}$ of total RNA.

\section{Statistical Analysis}

The data are expressed as mean \pm SEM and were analyzed by ANOVA followed by Student's $t$ test with Bonferroni's corrections.

\section{References}

Adner M, Cantera L, Ehlert F, Nilsson L, and Edvinsson L (1996). Plasticity of contractile endothelin-B receptors in human arteries after organ culture. $\mathrm{Br} J$ Pharmacol 119: 1159-1166. 
Aiello LP, Bursell SE, Clermont A, Duh E, Ishii H, Takagi C, Mori F, Ciulla TA, Ways K, Jirousek M, Smith LEH, and King GL (1997). Vascular endothelial growth factor-induced retinal permeability is mediated by protein kinase $C$ in vivo and suppressed by an orally effective beta-isoform-selective inhibitor. Diabetes 46:1473-1480.

Barnes K and Turner AJ (1999). Endothelin converting enzyme is located on alpha-actin filaments in smooth muscle cells. Cardiovas Res 42:814-822.

Berge KE, Djurovic S, Muller HJ, Alestrom P, and Berg K (1997). Studies on effects of Lp(a) lipoprotein on gene expression in endothelial cell in vitro. Clin Genet 52:314-325.

Bonner SM and O'Sullivan MA (1998). Endothelial cell monolayers as a model system to investigate dengue shock syndrome. J Virol Methods 71:159-167.

Brownlee M, Cerami A, and Vlassara H (1988). Advanced products of nonenzymatic glycosylation and the pathogenesis of diabetic vascular disease. Diabetes Metab Rev 4:437451.

Caballero AE, Arora S, Saouaf R, Lim SC, Smakowski P, Park JY, King GL, LoGerfo FW, Horton ES, and Veves A (1999). Microvascular and macrovascular reactivity is reduced in subjects at risk for type 2 diabetes. Diabetes 48:1856-1862.

Cameron NE, Dines KC, and Cotter MA (1994). The potential contribution of endothelin-1 to neurovascular abnormalities in streptozotocin-diabetic rats. Diabetologia 37:1209-1215.

Chakrabarti S, Gan XT, Merry A, Karmazyn M, and Sima AAF (1998). Augmented retinal endothelin-1, endothelin-3, endothelin $_{A}$, and endothelin ${ }_{B}$ gene expression in chronic diabetes. Cur Eye Res 17:301-307.

Chakrabarti S and Sima AAF (1997). Endothelin-1 and Endothelin-3 like immunoreactivity in the eyes of diabetic and non-diabetic BB/W rats. Diab Res Clin Prac 37:109-120.

Chakravarthy $U$, Douglas AJ, Bailie R, McKibben B, and Archer DB (1994). Immunoreactive endothelin distribution in ocular tissue. Invest Ophthalmol Vis Sci 35:2448-2454.

Chakravarthy U, Hayes RG, Stitt AW, and Douglas A (1997). Endothelin expression in ocular tissues of diabetic and insulin-treated rat. Invest Ophthalmol Vis Sci 38:2144-2151.

Cullinan-Bove K and Koos RD (1993). Vascular endothelial growth factor/vascular permeability factor expression in the rat uterus: Rapid stimulation by estrogen correlates with estrogen-induced increases in uterine capillary permeability and growth. Endocrinology 133:829-837.

Deng DX, Evans T, Mukherjee K, Downey D, and Chakrabarti S (1999). Diabetes-induced vascular dysfunction in the retina: Role of endothelins. Diabetologia 42:1228-1234.

Duh E and Aiello LP (1999). Vascular endothelial growth factor and diabetes: The agonist versus antagonist paradox. Diabetes 48:1899-1906.

Evans T, Deng DX, Chen S, and Chakrabarti S (1999). Hyperhexosemia induced extracellular matrix protein gene expression and basement membrane thickening in the retinal microvasculture are mediated via augmented endothelin production. Canad J Diab Care 23(Suppl 2):A46.

Evans T, Deng DX, Downey D, and Chakrabarti S (1998). Endothelins in hyperhexosemic retinal vascular dysfunction. Canad J Diab Care 22(Suppl 2): A19.

Greene DA, Lattimer SA, and Sima AAF (1987). Sorbitol, phosphoinositides, and sodium-potassium-ATPase in the pathogenesis of diabetic complications. N Engl J Med 316: 559-606.

Hopfner RL, McNeil JR, and Gopalakrishnan V (1999). Plasma endothelin levels and vascular responses at different temporal stages of streptozotocin diabetes. Eur J Pharmacol 374:221-227.

Ishii $H$, Jirousek MR, Koya D, Takagi C, Xia P, Clermont A, Bursell SE, Kern TS, Ballas LM, Heath WF, Stramm LE, Feener EP, and King GL (1996). Amelioration of vascular dysfunctions in diabetic rats by an oral PKC inhibitor. Science 272:728-731.

Kanai T, Konno H, Tanaka T, Baba M, Matsumoto K, Nakamura S, Yukita A, Asano M, Suzuki H and Baba S (1998). Antitumor and antimetastatic effects of human vascular endothelial growth factor neutralizing antibody on human colon and gastric carcinoma xenotransplanted orthotopically into nude mice. Int J Cancer 77:933-936.

King GL, Oliver FJ, Inoguchi T, Shiba T, and Banskota NK (1993). Abnormalities of vascular endothelium in diabetes. In: Marshall SM, Home PD, Alberti KGMM, and Krall LP, editors. Diabetes Annual. Amsterdam: Elsevier Publication, 107-126.

Kolodgie FD, Wilson PS, Mergner WJ, and Virmani R (1999). Cocaine-induced increase in the permeability function of human vascular endothelial cell monolayers. Exp Mol Pathol 66:109-122.

Koya D and King GL (1998). Protein kinase $C$ activation and the development of diabetic complications. Diabetes 47:859-866.

Levin ER (1995). Endothelins. N Engl J Med 333:356-363.

MacCumber MW, Jampel HD, and Snyder S (1991). Ocular effects of the endothelins: Abundant peptides in the eye. Arch Ophthalmol 109:705-709.

Malek AM, Lee IW, Alper SL, and Izumo S (1997). Regulation of endothelin-1 gene expression by cell shape and the microfilament network in vascular endothelium. Am J Physiol 273 (5 pt 1): C1764-C1774.

Matsuura A, Yamochi W, Hirata K, Kawashima S, and Yokoyama M (1998). Stimulatory interaction between vascular endothelial growth factor and endothelin-1 on each gene expression. Hypertension 32:89-95.

Nakamura T, Ebihara I, Fukui M, Tomuno $\mathrm{Y}$, and Koide $\mathrm{H}$ (1995). Effect of a specific endothelin receptor A antagonist on mRNA levels for extracellular matrix components and growth factors in diabetic glomeruli. Diabetes 44:895-899.

Pedram A, Razandi M, Hu RM, and Levin ER (1997). Vasoactive peptides modulate vascular endothelial cell growth factor production and endothelial cell proliferation and invasion. J Biol Chem 272:17097-17103.

Porta M (1996). Endothelium: The main actor in the remodelling of the retinal microvasculature in diabetes. Diabetologia 39:739-744.

Salameh A, Zinn M, and Dhein S (1997). High D-glucose induces alterations of endothelial cell structures in a cellculture model. J Cardiovas Pharmacol 30:182-190.

Sarman B, Toth M, and Somogyi A (1998). Role of endothelin-1 in diabetes mellitus. Diabetes Melab Rev 14:171-175.

Scudiero DA, Shoemaker RH, Paull K-D, Monks A, Tierney S, Nofziger TH, Currens MJ, Seniff D, and Boyd MR (1988). Evaluation of a soluble tetrazolium/formazan assay for cell growth and drug sensitivity in culture using human and other tumor cell lines. Cancer Res 48:4827-4833. 
Simonson MS (1993). Endothelins: Multifunctional renal peptides. Physiol Reviews 73:375-411.

Tarquini B, Perfetto F, Tarquini R, Cornelissen G, and Halberg F (1997). Endothelin-1's chronome indicates diabetic and vascular disease chronorisk. Peptides 18:119-132.

Vanhoutte PM (1994). Endothelins: A matter of life and breath. Nature 368:693-694.

Williamson JR, Chang K, Frangos M, Hasan KS, Ido Y, Kawamura T, Nyengaard JR, Van Den Enden M, Kilo C, and Tilton RG (1993). Perspective in diabetes: Hyperglycemic pseudohypoxia and diabetic complications. Diabetes 42: 801-813.
Yu PK, Yu DY, Alder VA, Su EN, and Cringle SJ (1998). Intracellular structures of retinal vascular endothelium in normal and early diabetic rats. Aust NZ J Ophthalmol 26(Suppl 1): S53-S55.

Zheng W, Chin TA, and Templeton DM (1996). Calciumindependent effects of cadmium on actin assembly in mesangial and vascular smooth muscle cells. Cell Motil Cytoskeleton 33:208-222.

Zhou X, Hurst RD, Templeton D, and Whiteside Cl (1995). High glucose alters actin assembly in glomerular mesangial and epithelial cells. Lab Invest 73:372-383. 